\title{
The Challenges and Difficulties in Teaching Listening: An Exploratory Research in a Junior High School in Kudus
}

\author{
Slamet Utomo \\ Muria Kudus University \\ slamet.utomo@umk.ac.id
}

\author{
Sri Endang Kusmaryati \\ Muria Kudus University \\ sri.endang@umk.ac.id
}

\author{
Titis Sulistyowati \\ Muria Kudus University \\ titis.sulistyowati@umk.ac.id
}

\begin{abstract}
The objectives of this study are describing the process of teaching English (listening) and identifying the difficulties in teaching (English) listening in a Junior High School in Kudus. This research uses exploratory research design. I will explore qualitative data to analyze the process of the teaching and learning English in Kudus and to identify the need of the learning materials. The subjects of the research are five English teachers' from a Junior High school in Kudus, they have been teaching English for more than ten years. They have been teaching from different classes, class 7, class 8 , and class 9 . This study has discovered the challenges and difficulties in learning and teaching in Junior High School in kudus. Most teachers feels that time management become their major challenge in organizing classroom. They have set lesson plan, but sometimes the lesson does not work exactly the same. They have to work with mixed-level students, with students with learning difficulties, and with learners who are coming from different backgrounds. Teachers should be aware that it is part of teachers' primary duty to cope with every student. Most students can learn a foreign language to some level, but there are many reasons why their improvements are not achieved significantly.
\end{abstract}

Key Words: Listening Skill, Challenges, Difficulties, and Teaching Listening

\section{INTRODUCTION}

For the speakers of other languages, learning English is a challenging process. There are many aspects that influence the success of learning English. One of the essential aspects is the learning material. Although the access to international communication is widely open on line through internet, there is no clear rule or regulation on how to use those facilities for language education.

In communicating by using foreign language, the EFL learners in Indonesia need some efforts in understanding and responding on the words they have just listen to. They need time before they could grasp the meaning of the words, especially if they are not in the level of the language proficiencies. Limitation of vocabulary has become their major difficulties in listening comprehension.

Brown (2007) states that in teaching is on the awareness of teachers to teach language not only on the level of linguistics rules and definition, but they should encourage student to communicate spontaneously and meaningful. To be able to communicate spontaneously and meaningful, students should have appropriate language competence. Nunan (2002) says that Listening as one of the language skill is essential not only as a receptive skill but also to the development of spoken language proficiency. 
There are obviously many differences among the students all over the world. Concerning to the background differences, the students also have different attitudes in the classroom. Thomson (2005) says that some teachers find that their students are often busy talking and chatting among others and do not concentrate on the listening subject. In listening students need full concentration on the audio being played, otherwise they may not catch the messages from the audio. Some students have low motivations because they are forced to be in the class and because they are not willing to learn. Some of them have problem on concentration and find listening is more difficult than other subjects. Students simply turn off when listening to spoken English as it is seem too difficult follow without high level of concentration.

Cahyono and Widiati (2009) state many aspects need to be considered in teaching listening in Indonesia. The first, EFL listening is integrated language skill. It is done integrated with other skills; speaking, reading and writing. The second, listening activities are designed to improve students listening ability. This concerns the development of various teaching and listening techniques that have been applied in English classrooms or in English language laboratories. The third is language teaching media used to teach EFL listening. The types of media may vary from the use of tape or $\mathrm{CD}$ players in the classroom to the use of multi-media language laboratory.

For language teachers in Indonesia, the aspects mentioned above can be the problems in the teaching processes. This may because the limitation of the listening resources and supportive facilities. In some cases, the main problem of listening courses can be from the listening course book itself. To follow directly the course book they have selected without any adjustment can cause listening problems. If teachers cannot adopt, edit or adjust the listening activities with the students listening level, the listening process may create the high tension and anxiety for students.

Listening in the level of Junior High School in Indonesia is considered at the level of beginner. The listening activities start from the word level, sentence level and meaning based level. Yavuza, Degirmencia, Akyuza, Yılmaza, Celika (2015) claim that the exercise types those early level pupils can be given are repetition which they are only expected to repeat what they hear, asking if what they hear is English or not and to decide if they hear the same or different utterances. Following a written text facilitates the students both read and listen to texst and see how words are pronounced or have the chance to see the actual listening and hearing of a native speaker.

The English teaching in Junior High School level in Indonesia seems pay less attention on the listening activities, most of the English text books are applying paper based design which are not equiped by audio aids. This research is done to explore the need of the listening material which is suitable for the early level students. As the part of the need analysis, we explore the process of the current teaching process and identify the difficulties and challenges faced by the English teacher.

Therefore this research focuses on (1) How is the process of teaching English (Listening) in a Junior High School in Kudus? (2) What are the teacher's difficulties and challenges in teaching (listening) in a Junior High School Kudus?

\section{THEORETICAL REVIEW}

\section{Teaching Listening}

Listening skill of second language is not derived naturally; it needs some processes of learning. The processes of listening in the classroom involve active interaction between teachers and students. In listening classroom, teacher can be the source of the listening itself or becoming the intructor and the manager 
when they use other listening cources. A lot of listening materials are derived from recorded extract, for instance on $\mathrm{CD}$, tape record, video and others.

Probably the main source of listening for students is the voice of their teacher. Individual voice of the teacher also can be called as the source of listening, because in teaching learning process, teacher talk as he is giving some instructions should also be understood by their students. But in fact the students need variety in listening then just listen to the teacher's voice.

Instead of doing listening activity in the classroom, the students should also practice their listening skill outside of the classroom. This kind of activity can be more challenging and fun. They can find any others materials everywhere, often on CDs, on MP3 players, videos or on the internet-should consist of text that they can enjoy listening too, because they more or less can be understood although without any intervention from their teacher for their do such kind of activity and practice their listening unconsciously. Probably the easiest way of practicing listening is by listening to songs. Many of the students enjoy sons very much, they will be curious on understanding the lyric as it may reflect his or her feeling. Another way is by watching English movie, as they see the set on the screen and listening to the dialogue. Although they may not understand the whole dialogue, at least they will know some parts and they will absorb the language gradually.

Richard (2008) sees listening in two different perspectives; listening as comprehension and listening as acquisition. Listening for comprehension is the traditional nature of listening. This views listening as the process of understanding the meaning in a spoken discourse, while listening for acquisition focus on listening as the process of deriving other shill such as speaking.

In understanding text as spoken discourse, Richards (2008: 4-7) introduces two different kind of processes. They are often referred to as bottom-up and top-down processing. Bottom-up processing refers to the use of the incoming input as the basis for understanding the message. Comprehension begins with the received data that is analyzed at the levels of organization - sounds, words, clauses, sentences, texts-until meaning is derived. Comprehension is viewed as a process of decoding. While Top-down processing, on the other hand, refers to the use of background knowledge in understanding the meaning of a message. Whereas bottom-up processing goes from language to meaning, top-down processing goes from meaning to language. The background knowledge required for topdown processing may be previous knowledge about the topic of discourse, situational or contextual knowledge, or knowledge in the form of "schemata" or "scripts"-plans about the overall structure of events and the relationships between them.

Buck in Richards (2008) identifies two kids of strategies in listening. The first is Cognitive strategy. It relates to comprehending and storing input in working memory or long term memory for later retrieval. Comprehension processes are associated with the process of linguistics and non linguistics input. Storing and memory processes are associated with the storing of linguistics. Using and retrieval processes are associated with assessing memory, to be ready for output. The next is Metacognitive Strategy. It refers to conscious or unconscious mental activities that perform an executive function in the management of cognitive strategy. This strategy involves assessing the situation, which is taking the surrounding of the language task by assessing one's own knowledge. Next is monitoring the effectiveness of one's own and another performance. The last is self evaluating performance after engaging in the activity and Self testing the performance to determine the effectiveness of one's own language use.

Listening O'Malley and Chamot in Vandergrift (1999) have differentiated and categorized the range of cognitive activity in 
language learning into two main types: metacognitive and cognitive strategies. Metacognitive strategies oversee, regulate, or direct the language learning process. These strategies, which involve thinking about the learning process, include planning, monitoring, and evaluating. Cognitive strategies manipulate the material to be learnt or apply a specific technique to the learning task. A third category, socio-affective strategies, was added to describe learning that happens when language learners cooperate with classmates, question the teacher for clarification, or apply specific techniques to lower their anxiety level.

Rost (2011: 2-4) purposes four listening orientation; receptive, constructive, collaborative, and transformative.

1. The first Orientation is receptive. It deals with receiving and catching what the speaker actually says. it focuses on getting idea, decoding the message, unpacking the content from the speaker. It involves the process of attending to, hearing, understanding and remembering aural symbols. Listening is receiving the transfer of images, impressions, thoughts, beliefs, attitudes and emotions from the speaker.

2. The second is listening for constructing and representing meaning. Listening means reframing the speaker's message in a way that's relevant to the hearer, understanding why the speaker is talking and noticing what is not said. Listening is the process by which oral language is received, critically and purposefully attended to, recognized and interpreted in terms of past experiences and future expectancies.

3. The third orientation is collaborative. Listening is negotiating meaning with the speaker and responding. it is the process of negotiating shared information or values with the speaker. Listening is signaling to the speaker which ideas are clear and acceptable. It involves haring the emotional climate. In conclusion, Listening is the acquisition, processing, and retention of information in the interpersonal context.

4. The last listening orientation is transformative. Listening is creating meaning through involvement, imagination and empathy. It is creating a connection between the speaker and the listener. Listening is the process of creating meaning in the speaker. Listening is the process of altering the cognitive environment of both the speaker and the listener.

\section{METHODOLOGY}

This research uses exploratory research design. We explore qualitative data to analyze the teaching and learning English in a Junior High School in Kudus and to identify the need of the learning materials. In analysing the data we use inductive approach. Inductive approach in this research involves the research pattern from observation and the development of the explanations from the subject of the research. We are not introducing theories or hypotheses in this inductive study at the beginning of the research. We possess the freedom in terms of creating the direction for the study after the research process had concluded. This research is intended to draw theories as the conclusion of the research.

The subjects of the research are five English teachers' from Islamic State Junior High School in Kudus, they have been teaching English for more than ten years. They have been teaching from different classes, class 7, class 8 , and class 9 .

Instrument of the research are questionnaires, interview and documentations. We use questionnaires to get the data of the teaching activity in a Junior High School in Kudus to answer the first research questions. The questionnaires are in form of teachers' reflection sheets. We conduct interview with the English teacher to identify the difficulties in teaching Listening. 
The data of this research are analyzed through several steps. The first is exploring the process of teaching English and identifying the difficulties in teaching English (listening). In this step we do interviews with the teacher in order to identify the difficulties faced by the teachers and to discuss the solution than can be used to overcome the problems. This data gain from open ended questionnaires to record the activities in class and semi structured interview to identify the challenges and difficulties. To analyze the whole data we classify them into two categories. The first step is calculating the percentage of the close ended questionnaires which explore the process of teaching and learning. The second step is coding and classifying the qualitative data which show the difficulties in teaching English in general and in teaching listening.

\section{FINDINGS AND DISCUSSION}

\section{Finding}

All teachers have already followed the steps of doing proper teaching and learning process. The activities range from the apperception, whiles teaching and closing.

In doing apperception teacher prepare the students by rearranging the seat and dividing the group. The seating arrangements usually are changed at every occasion based on the learning purposes. The teachers also consider the students capability in dividing them into groups. In giving apperception, teachers usually give questions related to the material given and also the purposes of the teaching and learning. The questions are varied depend on the students competence, some can be analytical one. This activity is used to motivate the students and to raise the students' enthusiasms.

In whiles teaching phase, teacher give the material and tries to understand the material well. They also extend the material by making some adjustment to the students' daily context. The teachers also guide the students in doing the task. They guide them by providing clear instruction, both verbal and nonverbal instruction in order to make the students to do the task well. In explaining the material, teachers also focus on the students understanding. Explanation is done by maximizing the use of verbal and nonverbal language. Teachers also adjust the volume of their voice base on the condition of the classroom, to control the students and to maintain interaction. In the lesson plan, the teachers include the objectives of the lesson and arrange all the activities to adjust the time allocation, although sometimes the teaching and learning may be not happened exactly the same due to the time allotment.

The material given during the lesson has already supported by technology, like the equipment which support audio and video playing. The teaching aids usage depends on the need of the learning material. These aids should be able to be used to support the success of the learning outcome. This aid should also facilitate the students' enthusiasms.

In building the students report, teachers try to distribute the same chances to students to participate in the classroom activities. They show openness to respond to students who actively raising questions when they get difficulties. Teacher also appreciates the students who answer questions correctly and honor the students' willingness to participate. They stimulate the students' confidence in participating classroom discussion and manage students' anxiety by creating comfortable atmosphere.

The closing activities are done by summarizing and concluding the lesson to check the students' understanding on the subject. Teachers also give the students some assignment as remedial assignment or to extend their understanding. This has purpose to connect the learning material into the students' context. 
Table 1. The Result of The Teacher Questionnaires

\begin{tabular}{|l|c|}
\hline Pre teaching & \\
\hline Preparing the students by grouping and organizing the seats & Yes \\
\hline Doing apperceptions by introducing the materials & Yes \\
\hline Whiles teaching & \\
\hline Delivering the Material & Yes \\
\hline Preparing the material well & Yes \\
\hline Giving instruction clearly & Yes \\
\hline Delivering the material well by using clear language and gesture & Yes \\
\hline Manage the quality of voice (to make the students listen to the teachers' voice & Yes \\
\hline Creating the teaching and learning base on its purposes & Yes \\
\hline Managing the teaching and learning base on the time allocation & \\
\hline The use of media as learning sources & Yes \\
\hline Using media appropriately and effectively & Yes \\
\hline Using media base on the teaching material & Yes \\
\hline Using media which create the students' enthusiasm & \\
\hline Building students rapport & Yes \\
\hline Giving students chances to participate & Yes \\
\hline Showing open attitudes to students critics & Yes \\
\hline creating students' fun and enthusiasm for students learning environment & \\
\hline Closing & Yes \\
\hline Doing reflection and making conclusion base on the students' involvement & Yes \\
\hline $\begin{array}{l}\text { Making follow up by using clear instruction, students' activities, or remedial as } \\
\text { additional assignment }\end{array}$ & \\
\hline
\end{tabular}

The teachers claim that they do have many difficulties in preparing the listening material based on syllabus, because the material has not been prepared by the government. Although the material has already available, it seems that students still need adjustment. The students have limited vocabulary to understand the listening text. Furthermore students have limited time to listening exposure. Their listening exposure is still at the level of words and sentences.

Table 2. The Result of Teachers' Difficulties in Teaching Listening

\begin{tabular}{|l|c|c|c|}
\hline \multirow{2}{*}{ Listening Difficulties } & \multicolumn{3}{c|}{ Answer } \\
\cline { 2 - 4 } & Yes & No & Sometimes \\
\hline $\begin{array}{l}\text { Difficulties in preparing the listening material based in } \\
\text { syllabus. }\end{array}$ & & $\mathbf{1 0 0 \%}$ & \\
\hline Students have difficulties in understanding vocabulary & $\mathbf{6 0 \%}$ & & $\mathbf{4 0 \%}$ \\
\hline Classroom facilities do not support the listening activities & $\mathbf{6 0} \%$ & & $40 \%$ \\
\hline Limited time allocation in Listening activities & $\mathbf{6 0 \%}$ & $\mathbf{4 0 \%}$ & \\
\hline
\end{tabular}




\section{DISCUSSION}

\section{The Teaching Process}

The teaching activities in Junior High School in Kudus start from the pre teaching activity. Before beginning the class the teachers usually start by using apperception to start up every student in the classroom. In this section, Teacher reminds the student about the lesson given in the previous meeting. Teachers try to prepare the students psychologically and physically to study by asking about the previous meeting.

The main goal of this activity is to connect the previous lesson to the next lesson. Teachers inform the students what they are going to learn today and how important it is for their daily activity. Teacher gives motivation to the students with explanation how important to study it.

Because the class consists of many students it occasionally becomes necessary to divide them into groups. Teachers manage the students into groups to make the lesson runs effectively. The teachers realize that students have different capability and ability, therefore it needs to be arranged base on the purpose, whether they have to be in group with the same or combination of level of proficiencies. Teachers have been trying out this concept to classes with huge number of students. Because students also need to work in groups on a full time basis, the sitting arrangement should also be adjust to make sure that every student has a chance to participate and sit in their most comfortable zone.

During the teaching process, teachers also use various techniques in teaching. It is meant to avoid students' boredom because technique really influences students' interest. The technique which is applied by the teacher to teach English is varied. The media is concerned with deriving new vocabulary item in text. In teaching, the teacher uses some Islamic approach and national character education to build students' characteristics. The local values are also becoming the main issues to be introduced and instilled to the students.

So in the process of teaching, the teachers always use Islamic approach to build students' characteristics. It is because the socio culture in Kudus is based on Islamic culture. Islamic approach is approach that considered and adopted from Islam. National character was also used because this school also used the curriculum set by the Indonesian government. The characteristics building in this school is an important thing because it is also one of State Islamic School in Kudus. The students do not only learn science and knowledge but the school also educates and develops students to have good personalities.

Before the lesson begins, teachers do some preparation by designing lesson plan. Teachers try to follow the plan, but it is not always happened exactly the same. Sometimes the teaching and learning do not run exactly like the lesson plans. It is happened when the students curious to know other materials by giving many critical questions. Therefore a teacher should made preparation by understanding the material well, in order to make the teaching and learning process run successfully. By making the lesson plan, the teachers have an outline to keep the lesson work as it is supported by the government.

Grossman (1990) states that teaching must be planned in such a way that learning became an interesting, even at time entertaining process. So, the preparation before teaching is needed to make the process of teaching successful.

In starting the class, the teachers always start the lesson by greeting the students based on Islamic culture. They say 'Salam' and all students answer the teacher. While the teacher enters the class, all students have been ready to study. Before starting the lesson, the teacher always asks the captain of class to lead the prayer. It is the culture of this Islamic school, so before starting the lesson 
they should pray first and after that teacher explains the lesson.

In teaching process, at first the teacher explains by using English and then they sometimes repeat it into Indonesian to avoid misunderstanding. In explaining the lesson, teacher uses code mixing because not all students understand English well. The use of L1 is dominating the class, in order to adjust the students' language and culture. To stimulate the classroom English, the teacher tries to make the students used to listen English and also makes them used to speak using English so they will be able to understand English and produce English by speaking.

In applying teaching technique, the teacher sometimes uses audio visual to improve the students' listening comprehension. They use media to attract students' attention namely video on many different texts. In Junior high school level, it is difficult to give the students listening experience, none of the book give listening section. The materials tend to emphasize on the reading and writing only, therefore teachers should be active in creating listening material for their students.

Audio video is used by the teacher to make them memorizing vocabulary they need to master which is used in the video. The use of audio for introducing some vocabularies to students will help the students and teachers to learn pronunciation. It is hoped that the students can pronounce the word correctly because they have the right model of pronunciation.

Besides giving suitable teaching material, giving assignment, and joke, the teacher also give students motivation. In giving students motivation, they used various ways. Because each student has unique characteristics, in giving motivation teacher also use specific ways. Young students like to be appreciated in every way they do in the lesson, therefore teachers used many appraisal, like well done, great, good job, or just simply say thanks. These words give them such a joyful atmosphere in following the lesson.

After the process of teaching and learning, the teachers summarize the materials by making question and answer session. This activity gave the teacher illustration of learning evaluation to know the success of the teaching and learning. This evaluation showed the result of teaching and learning which has been done. By giving evaluation, the teachers evaluate their success in delivering material. In giving evaluation, the English teacher used two kinds of evaluation; theoretical and practical evaluation. In theoretical evaluation, the teacher gave some questions to students and they had to answer the question. The result is in form of direct question and answer and questions and answer sheets. The teacher also asked students to practice, for instance, pronouncing words on video and making conversation with the teacher. The evaluation intended to make students able to produce English both written and oral.

Related to the national character education, this school has applied character based national education in teaching. It is stated in lesson plan and then applied in the process of teaching. In applying character national education, this school combined it with Islamic character so students have strong guidance in building their good characteristics.

To make the teaching process run successfully, teachers should understand about the students' character. By understanding the characteristics of each student, they will know how to treat them appropriately. Every student has different character and learning style, and as professional teachers, they should aware. Teachers should try to understand what students want. In teaching listening, the teacher was expected to be creative. The teachers can create a condition in which the students relax and enjoy the learning activities. 
To connect the learning materials to context of situation and society, teachers give real example and relate those to students' daily activities. It was very interesting since young learners are easy to understand by providing them the real example. Contextual teaching method will help the students to apply their knowledge into useful communication.

To create comfortable atmosphere in the class, the teacher should avoid of frightening or threatening them. In the process of teaching listening, the teachers usually interact with students in the questions and answer session. It uses to build their confidence around of their friends during the class.

To build up the students' rapport, the teacher often gave a joke to students if they look bored. When the students laugh, it indicates that the learning process is no longer stressful and frustrating. The students will find a way how to connect themselves with the material and also with the teacher as their supervisor. As a supervisor, in improving students' ability in listening and speaking English, the teacher used to guide them directly. It means that the teacher give more attention to the students' difficulties. By giving the students appreciation teacher also show good willingness and attitudes.

\section{Teaching Difficulties and Challenges}

The interview was conducted to explore deeper information about EFL teachers' difficulties at Junior High School in Kudus in teaching English. There is actually one major question of this research: What are EFL teachers' difficulties in teaching English at junior high school schools? The findings of the study revealed the facts that there were many challenges faced by EFL teachers at junior high level in teaching English. There are three major problems with the practice of teaching and learning English at the research sites, including finding out appropriate material: Insufficient time, resources, and materials and other problems; limited time, limited resources, limited facilities, and difficult materials.

Some teachers feel that preparing students to work in group sometimes it takes more time. They need to think whether they would like to group the students with the same capability of with different capability. Each student has different characteristics and not every student is willing to work with other students. This group work might offer the students chances to learn from each other, but it may also create new problem like personal conflict. There are many factors influence the quality of working together in group project. The first problem is trust. Trust is crucial in teamwork, and it starts with students knowing each other. Team members need to be connected, both professionally and personally. Sometimes members do not understand each other, they do not want to engage because there might be students' personal problems among members. This kind of problem may as an effect of individual way of thinking.

When the students become very enthusiast the class turns to be very noisy and overcrowded. The participants mentioned that their classes are over-crowded consisting more than 30 students. This condition affects the teacher's feeling and expectation. They shared that they did not enjoy teaching the class, and the situation led to ineffective classroom atmosphere. In addition, the participants also emphasized the further effect of too many students in the classroom, such as being noisy and loud.

In managing the class situation, teacher admits that they need more energy. Teachers need to adjust the voice to make the students listen to the teachers' voice clearly. In a large class, the situation can be very crowded and confusing. To be able to control the class, teachers should be able to turn up the volume of their voice without shouting or giving over threatening tone.

The students limited vocabulary also becoming one of the problems in teaching English. To be able to understand the English 
students just listen, the students need to increase their vocabulary mastery. Vocabulary development plays an important role in improving the students' level of language proficiency, but many students appear to have reached limited vocabulary. This may be seen in the overuse of simple vocabulary and failure to acquire new complicated vocabulary. In terms of the quantitative dimension of vocabulary learning, vocabulary development in Junior high school in Indonesia can be thought as in a low level of achievement. Teacher should stimulate students' vocabulary in different different text types. Learners build up vocabulary related to their own needs and fields of interests,

There are some listening activities which are done by the teachers. Repetition is the simple way of practicing pronunciation through listening activities, the teacher do such kind of activity to stimulate the students' vocabulary and speaking ability. Other activities with similar purpose are completing missing part. Teachers give the transcription to the students and omitting some words to let the students fill the gap. Listen and answer the questions activities can be done to check the students understanding on the what, where, why, and when. Wh-questions will explore the students understanding on specific information in the text.

Group discussion is set up to create chances to the students to be able to share their ideas and thought. To give the students to produce response to a certain topic, teachers ask them to present their thought. The process of listening is the process of acquiring other skill. Listening and speaking are considered as receptive and productive skill in language learning. A presentation and discussion in the class will provide the opportunity for the students to communicate and share their prior knowledge. A suitable listening material presented for the students should deliberately improve the students' comprehension and students' language acquisition. As the students learn the new knowledge, students will learn the form of the English expression in the video or audio recording.

\section{CONCLUSION}

Based on the result of interview, and teachers' reflection, it was found that teaching listening on oral text using video is a new technique. The school uses Kurikulum 2013 as the curriculum. School has followed the government's rule to apply national character in lesson plan. Based on the result of observation about implementation of teaching English at Junior High school in Kudus, it was found that in teaching English, the English teacher adjust the learning with the lesson plan. Before they start teaching and learning, teachers prepare the lesson plan based on the format which has been design by the government. They apply the lesson plan in the classroom which some adjustment based on the current situation.

This study has also uncovered the challenge and difficulties in learning and teaching in Junior High School in Kudus. Most teachers feel that time management become their major challenge in organizing classroom. They have set lesson plan, but sometimes the lesson does not work exactly the same. They have to work with mixedlevel students, with students with learning difficulties, and with learners who are from challenging backgrounds. Teachers should be aware that it as part of teachers' primary duty to cope with every student. Most students can learn a foreign language to some level, but there are many reasons why their improvements are not achieved significantly.

\section{SUGGESTION}

The educational policy in the country has decided that the Ministry of National Education is establishing a new curriculum by July 2013. The curriculum is intended to emphasis the character building of the students to correspond to the Principles of the 
State, Pancasila and the 1945 National Constitution. Competencies as well as Basic Competencies has been design and apply in the lesson plan of the English teachers in Junior High School. The implementation of this curriculum for English subject has been applied at all Junior High School level. However there are many aspects which might not be able to directly apply in the classroom doe to limitation of human resources and natural resources. Therefore some adjustment should be done based on classroom evaluation. The students' proficiencies improvement should be the main consideration to design classroom learning activities.
The listening module draft can be design based on the four listening orientation; receptive, constructive, collaborative, and transformative. The design will also adopt the listening approaches suggested by Richard, they are top-down and bottom up listening approach. The listening activity in the module will be started by applying bottom-up approaches. This is intended to stimulate the students' understanding by focusing on word meaning. The top-down approaches is done to introduce the topic to the students. It is done by using other visual aids, such as pictures. This approach also intended to give variation on language learning to connect the information in the text with the students' actual life.

\section{REFERENCES}

Brändström, C. (2011). Using the Internet in Education - Strengths and Weaknesses. Retrieved on August 1st on: http://www.diva-portal.org/smash/get/diva2:438827/FULLTEXT01.pdf

Brown, H. D. (2001). Teaching by Principles: An Interactive Approach to Language Pedagogy. New York: Longman

Brown, H. D. (2007). Principles of Language Learning and Teaching. USA: Longman

Cahyono, B.Y., \& Widiati, U. (2009). The teaching of EFL listening in the Indonesian context: The state of the art. TEFLIN Journal, 20(2), 194-211

Doughty, C., \& Williams, J. (1998). Focus on Form in Classroom: Second Language Acquisition. Melbourn: Cambridge University Press

Flori, F.D. (2014). Using information and communication technology to enhance language teaching and learning: An interview with Dr. A. Gumawang Jati. TEFLIN Journal, 25(1), 139-146.

Grossman, P. (1990). The Making of a Teacher. New York: Teachers College Press.

Harmer, J. (2007). How to Teach English. Edinburg Gate: Longman.

Harmer, J. (2007). The Practice of English Language Teaching. Edinburg Gate: Longman

Nunan, D., \& Miller, L. (2002). New Ways in Teaching Listening. Illinois: TESOL inc

Richards, J.C. (2008). Teaching Listening and Speaking: From Theory to Practice. New York: Cambridge University Press

Rost, M. (2011). Teaching and Researching Listening. Edinburgh Gate: Pearson Education Limited

Suarcaya, P. (2011). Web-Based audio material for EFL listening class. TEFLIN Journal, 22 (1), 5971

Thomson, K. (2005) Helping Teen to Listen. BBC British council. http://www.teachingEnglish.org.uk/think/listen/teen_listen.shtml. (accesssed 4th October 2017) 
Vandergrift, L. (1999). Facilitating second language listening comprehension: acquiring successful strategies. ELT Journal, 53(3)

(file:///D:/engl\%20teaching\%20article/Facilitating_second_language_listening_c.pdf) retrieved January 1st 2019

Yavuza, Degirmencia, Akyuza, Yllmaza, Celika. (2015). Problems and activities in listening skills in EFL classrooms; from tradition to a more comprehensible input. Social and Behavioral Sciences, 197, 930 - 932 